\title{
Senior High School Second-Grade Language Students' Perceptions on the Use of YouTube Videos
}

\author{
${ }^{1}$ Vania Marella Sugiarto, ${ }^{2}$ Listyani*, and ${ }^{3}$ Ardiyarso Kurniawan \\ ${ }^{1,2,3}$ PBI UKSW, Salatiga, Indonesia \\ ${ }^{1} 112016031 @$ @student.uksw.edu \\ 2listyani.listyani@uksw.edu \\ 3 ardiyarso.kurniawan@uksw.edu \\ (*corresponding author)
}

Article History: Submitted April $6^{\text {th }}, 2021$; Accepted November 11 ${ }^{\text {th }}, 2021$; Published December $13^{\text {th }}, 2021$

\begin{abstract}
YouTube is a website that provides a lot of videos from all over the world. Then, YouTube also offers many benefits for the educational area, such as for learning a language. This study aimed to discover a private Senior High School second-grade students' perceptions of using YouTube videos in language learning. The participants of this study consisted of ten second graders of language programs in that Senior High School. The data in this study were gathered by distributing open-ended questionnaires and doing some semi-structured interviews. This study found that YouTube has been very familiar to the students because most students watched YouTube every day for almost five hours. However, students faced some challenges and difficulties while learning the language through YouTube videos. Hopefully, this study can be useful for teachers and students to use YouTube effectively to learn languages.
\end{abstract}

Keywords: YouTube; perceptions; language-program students; language learning.

Abstrak. YouTube adalah sebuah situs internet yang menyediakan banyak video dari seluruh dunia. Situs ini menawarkan banyak manfaat dalam bidang pendidikan termasuk pembelajaran bahasa. Penelitian ini bertujuan untuk mengetahui persepsi siswa kelas dua sebuah SMA swasta tentang penggunaan video dari situs YouTube dalam pembelajaran bahasa. Responden penelitian ini terdiri dari sepuluh siswa kelas 2 dari sebuah program bahasa di SMA tersebut. Data diperoleh dari kuesioner "open-ended" dan juga wawancara "semi-structured". Dari data, ditemukan bahwa YouTube sudah sangat dikenal dikalangan siswa karena sebagian besar siswa menonton vdeo YouTube setiap hari selama hampir lima jam. Namun demikian, ada juga beberapa tantangan dan kesulitan yang di hadapi siswa saat belajar bahasa melalui situs YouTube. Penelitian ini diharapkan bisa bermanfaat bagi guru maupun siswa dalam belajar bahasa melalui YouTube sebagai sarana belajar yang efektif.

Kata kunci: YouTube, persepsi, mahasiswa program bahasa, pembelajaran bahasa

\section{INTRODUCTION}

In this digital era, technology has become an important thing that takes a big part in every aspect of human's life. From children until adults, almost all people use technology in their daily lives every day and everywhere. Technology brings many benefits to human life, especially in the educational area. In education, technology can provide many interesting sources for teaching-learning activities. It also can be used to enhance students' language learning experience (Muhammad, 2012). Furthermore, students in this modern era are very familiar with technology, so using technology in their learning will not be a problem. One of the ways to use technology is by using the Internet. 
Nowadays, the Internet enables people to find information from all over the world that can be accessed everywhere and every time. In the educational area, the Internet also offers a lot of interesting language learning materials.

An example of the use of the Internet in education is by using YouTube videos. YouTube is one of the most popular online platforms that provide a lot of videos from all over the world. This platform also gives many benefits and impacts on the teaching-learning process. YouTube videos provide an authentic situation that can help the students better understand the lessons (Muhammad, 2012). Using videos also enhances students' language skills because students can receive utterance and visual stimuli simultaneously (Kabooha and Elyas, 2018). Furthermore, as a familiar platform, YouTube can enhance students' motivation in language learning. Besides that, YouTube also can be used to increase students' creativity. It is because YouTube allows people to upload their videos. Therefore, teachers can upload their teaching materials while students can share the products from their learning.

Considering the benefits of YouTube videos in the classroom, it can be seen that YouTube videos are very beneficial for language learning. For that reason, the use of YouTube videos needs to get more attention. Therefore, this study was conducted to find out students' perceptions of using YouTube videos in language learning. Similar studies had been done by several researchers before. However, most of them, such as Muhammad (2012), Kabooha and Elyas (2018), Tamelan and Listyani (2018) were focusing on junior high school students and university level students. For those reasons, this study focused on senior high school students to make it different from the previous studies.

This study aimed to find out about students' perceptions of using YouTube videos, especially for the second graders of Language students in senior high school on language learning. This study hopefully can be helpful for teachers to use it effectively in the English teaching process and for learners to be more aware of the benefits of YouTube videos on their language learning. The more specific research question of this study was more focused on: What are the Senior High School second-grade students' perceptions about the use of YouTube videos in language learning?

These days, technology is commonly used as an important tool that gives a lot of benefits, especially on language learning. Bull and Ma (2001) stated that technology offers unlimited sources and materials for language learning. Similar to that, Almurashi (2016) said that a lot of online materials such as a website for learning and an incredible source of information can be found through technology. Based on the statements above, it can be seen that technology provides teachers and students with many materials and information which can be really helpful for the teaching-learning activities. Moreover, Gorra and Bhati (2016) asserted that accessing information through technology helps students improve their thinking and creativity in learning tasks and find strategies that can improve their learning quality. It can be seen that technology can be very helpful to develop students' creativity in learning something and finding their own strategies, which can increase their learning quality.

According to Leung (2004) as cited by Watkins and Wilkins (2011), technology in the language learning classroom can improve student autonomy and in-still lifelong language learning skills. Using technology in the teaching-learning process that differs from traditional teaching (whiteboard and marker) will make the teaching process appear more attractive. Syamlee and Phill (2012) stated that using technology featuring audio and visual effects in the learning process can increase students' interest and motivation in the study. Then, students are more cooperative in classroom activities or assignments when technology is used in the classroom (Baker, 2000). Moreover, Syamlee and Phill (2012) also said that students gain more confidence when technology takes part in teaching-learning 
activities. Therefore, it can be concluded that the use of technology in the classroom can increase students' motivation, interest, and self-confidence, making the students willing to participate in the teaching-learning activities.

There are different types of technology for language learning and teaching such as Computers, C.A.L.L, Internet, Videos, DVD's or VCD's (Syamlee and Phill, 2012). However, the technological resources which used the most in teaching and learning activities are computers, laptops, and mobile phones (Gorra and Bhati, 2016). In addition, one of the technologies which provide a lot of video sources is YouTube. YouTube is a video hosting service that enables people to upload, share, and view videos (Duffy, 2008). It was created on February 14, 2005, by Chad Hurley, Steve Chen, and Jawed Karim. Then, this site was bought by Google in September 2006 and moved to San Bruno California, in October. On YouTube, people can find a lot of content such as music videos, TV clips, and also personal videos uploaded by some users (Roodt and Peier, 2013). Anyone with the Internet can access videos.

Referring to its slogan "Broadcast Yourself" and its popularity, YouTube can be used to entertain, educate, and inform people by every video creator. The videos on YouTube are posted by many people, including amateurs and professionals, also viewed by people from many backgrounds. This implies that YouTube is impactful for people in the world.

There are a lot of benefits offered by YouTube for learning purposes, especially in English learning. Muhammad, 2012; and Almurasi, 2006 claimed that YouTube is one of the most effective tools in helping students to understand their English lessons. The use of YouTube in learning is considered an effective tool because videos can provide visual support and offer variety and entertainment (Allan, 1985). The visual support enables the students to see where the action is taking place, which helps the students understand more about the setting of a communication (Lonergan 1984). Therefore, YouTube videos can provide students with good knowledge and understanding of their lessons (Muhammad, 2012). Moreover, Muhammad (2012) also stated that the memory will be kept for a long time with better understanding. Therefore, the visual support provided by YouTube videos will be beneficial for students to understand and memorize their lessons.

Using videos in the classroom is also useful to increase students' attention, concentration, interest, and imagination makes the learning process more fun (Roodt and Peier, 2013) because it has many other features that can attract the students. For example, many games and attractive pictures are provided by YouTube (Tamelan and Listyani, 2018). With some games and pictures, students will have more interest in the learning process. Besides that, various kinds of content can be found on YouTube, so the students will not get bored.

As an effective tool for learning English, YouTube videos can help students improve their English skills. Based on Kabooha and Elyas (2018), YouTube greatly improves students' vocabulary acquisition. Using videos in the classroom is beneficial for vocabulary development and enhances students' listening and speaking abilities (Watkins and Wilkints, 2011). Therefore, using YouTube videos on English learning, students' vocabulary, listening, and speaking skills will be developed.

The use of YouTube videos in learning can be very useful but also have some limitations or challenges. Based on Burke, Snyder, and Rager (2009), videos on YouTube are not always accurate and credible. YouTube features that enable all users to share their videos can be one of the weaknesses of learning with YouTube. Because of that, some videos can lead the students toward incorrect information or misunderstanding. Besides that, YouTube videos may contain inappropriate contents 
that can be harmful to the students (Yuen, 2015 in Tamelan and Listyani, 2018). This happens because YouTube is used not only by children but also by adults. For that reason, many contents should not be seen by the students, such as violence, drugs, pornographies, and curse words. Moreover, many advertisements contain harmful contents which can appear when students watch a video.

The other challenge when using YouTube in the classroom is the misuse of technology. When technology is used in the classroom, there is a high possibility that students use YouTube for different purposes. Gorra and Bhati (2016) said that some students might watch movies or videos unrelated to the topics. Moreover, if they use their gadget, they might use it for playing games or chatting with their friends, which can distract the others. Therefore, teachers and parents should give more attention because some students may use YouTube for different purposes (Tamelan and Listyani, 2018) and protect them from harmful content.

There are some studies related to the use of YouTube videos in language learning or the classroom. In 2012, Muhammad researched to find out the effect of using YouTube on Literature students' performance. The study was conducted at Al-Majma'ah University or Al-Majma'ah community college. The result of this study shows that students can use YouTube effectively for learning and also give positive feedback about the use of YouTube in the literature course. Besides that, this study recommends the use of YouTube as a supplementary source for teaching language.

Similar to that, Kabooha and Elyas (2018) investigate English as Foreign Learner (EFL) students and teachers' perceptions about the use of YouTube for vocabulary learning. The study was conducted at King Abdul Aziz University. The result of this study shows that YouTube has a significant effect on students' vocabulary acquisition. Besides that, the participants positively viewed the use of YouTube in their lesson.

Another study was done by Tamelan and Listyani in 2018. The study was conducted to investigate junior high school students' perceptions of the use of YouTube videos for learning English. The result of this study shows that YouTube can improve students' understanding of English and their comprehension in listening, pronunciation, and vocabulary skill.

From those studies above, it can be seen that YouTube gives positive results for the students. The study conducted by Muhammad in 2012 shows that students like to use YouTube in their learning, so the study suggests English teachers to try using YouTube in their English teaching. On the other hand, Kabooha and Elyas (2018); and Tamelan and Listyani (2018) which focused on students' perceptions find out that YouTube videos on language learning can improve students' listening, pronunciation, and vocabulary skills. From some studies above, it can be seen that YouTube videos could be beneficial for teachers and students. Teachers and students should be more aware of the benefits of YouTube videos on language learning and use them effectively.

In conclusion, technology gives a lot of benefits for teachers and students in the language learning process. Videos are one of the examples of the use of technology in the teaching-learning process. Then, videos for teaching or learning materials can be found easily through YouTube. Nowadays, YouTube videos have become more popular in English teaching and learning. It happens because YouTube videos for English language learning offer many benefits. For example, YouTube videos provide visual supports which enhance students' understanding and interest in the lessons. YouTube also provides a lot of contents which enable teachers to create interesting materials and learning activities. Moreover, YouTube enables students to improve their listening and speaking skills and also their vocabulary acquisitions. 
On the other hand, there are some limitations and challenges to using YouTube in language learning. For example, not all information from YouTube videos is accurate or credible. Some videos might lead to incorrect information. Then, many contents and advertisements contain inappropriate content such as pornographies, drugs, bullies, etc. Besides that, some students might use YouTube for other purposes, disturbing the learning process. Therefore, while YouTube takes part in the teachinglearning activities, teachers and parents must give more attention to protect the students from those limitations and challenges.

\section{METHOD}

This study aimed to figure out private Senior High School students' perception of using YouTube videos in their English learning. Therefore the research was focused on: What are the Senior High School second-grade students' perceptions about the use of YouTube videos in language learning?

To achieve the objective of this study, a qualitative approach was used. Jackson, Camara, and Drummond (2016) asserted that the qualitative approach is used to find out about certain attitudes, trends, or opinions by studying the sample of the populations. Then, Based on Creswell (2014), the characteristic of the qualitative approach: takes place in the natural setting, researchers is the instrument for data collection, use multiple methods of data collection, both inductive and deductive, based on participants' meanings, includes researcher reflexivity, and is holistic. In this research, the answers from the questionnaires and the interview results were analyzed to be qualitative research.

This study was conducted in the second semester of 2019/2020. The setting of this study was in a private Senior High School in Semarang, Central Java, Indonesia. This school is one of the private senior high schools in Semarang, which has a language program. Moreover, this school also used YouTube videos as one of the English learning sources. The researchers chose language class students because they learned the language, especially English, more than the other programs.

The participants were all second graders of language program students in the Senior High School, consisting of ten students. The second graders were chosen because of some reasons. First, the firstgrader students had not chosen their programs yet, so there are no language programs from the first graders. Second, the third graders' students were focusing on the national exam material, so they did not learn the language as much as the second graders. For those reasons, the second-grader students were chosen because their learning materials were focused on language, emphasized more on language development, and used YouTube videos more than other grades.

In this study, open-ended questionnaires and semi-structured interviews were used to gather the data. The questionnaires were used to find out background information about the use of YouTube videos, such as how often they watched YouTube and how much time the students usually spent watching YouTube. The questionnaires were written in Indonesian to make sure the students understood the questions. Besides that, the open-ended questionnaire was chosen because it enabled the students to share their opinion more freely. The questionnaires consisted of eight questions. The questionnaires were adapted from Tamelan and Listyani (2018).

After finishing the questionnaires, the interview was conducted to get more detailed information. The interview also used Indonesian to give more chances for the students to share their opinions. Based on Dawson (2009), semi-structured interviews are used to get specific information and flexible enough to resolve other important issues. Therefore, the semi-structured interview enabled the student 
to speak more freely and also enabled the researchers to ask follow up questions which were not written in the interview protocol. The interview consisted of five questions. The interview questions were adapted from Tamelan and Listyani (2018).

There were several steps to collect data. Based on Creswell (2004), the first rules of collecting data was respected the site and not disrupted the research site. Therefore, the first step to collecting data in this study was asking for permission to the school principal and English teachers of the school. Besides that, the research was done after the teaching-learning activities had been done to avoid disturbance for the research site. As the second step, the researchers distributed the questionnaires to the students and asked them to fill them out. Creswell (2004) also stated that all participants should receive benefits or beneficial treatments. For those reasons, after distributing the questionnaires, the researchers gave some merchandise and snacks to the participants. The purpose was to make the participants willing to participate in the research and got good treatments.

After that, the researchers gathered all the questionnaires and the answer from the students. From the result, the researcher chose two students who completed the questionnaires appropriately and filled the consent form to be interviewed. Creswell (2004) added that when the interview is conducted, the researchers must avoid exploiting participants and collecting harmful information. Therefore, the researcher was asking permission from the interviewees before recorded the interviews. Besides that, the researchers promised to keep the confidentiality of the participants' privacy. After the interview finished, the results were transcribed and analyzed.

Data analysis was done based on the result of the questionnaires and the interviews. After gathering all of the questionnaires, the researchers read all of the answers. After that, the questionnaire results were classified. Then, the interview records were transcribed to get the interview results. Creswell (2014) said that researchers must respect the participants' privacy. Because of that, information regarding the participants' identity did not show in this study. The researchers used the initial name to replace the participant identity. The results of the questionnaires and the interview were shown as qualitative data. Last, the results from the questionnaires and the interviews were analyzed to find out the students' perspective about the benefits of YouTube videos in language learning.

\section{RESULTS AND DISCUSSION}

In this section, the answers from the questionnaires and the results of the interview were analyzed qualitatively. The results of the interview had been transcribed and classified. The findings found that most student participants perceived YouTube as a positive tool that helped them enhance their language skills such as vocabulary acquisition, listening, and pronunciation skills.

\section{Students' Perceptions on YouTube Videos for Language Learning: The Benefits}

According to the questionnaires and the interviews, students had various perceptions about the use of YouTube videos on language learning. Nine out of ten students $(90 \%)$ agreed that YouTube videos positively affected their learning. There were some perceptions about the benefits on the use of YouTube videos for Language Learning:

\section{Being well-known by students}

As the third most visited website on the Internet (Muhammad, 2012), YouTube has become very familiar. According to the questionnaires, YouTube was used regularly by the second graders of 
language students in the private Senior High School. Figure 1 shows that nine out of ten students watched YouTube videos every day and only one student watched YouTube videos three times a week. It proved that the students had been very familiar with YouTube videos.

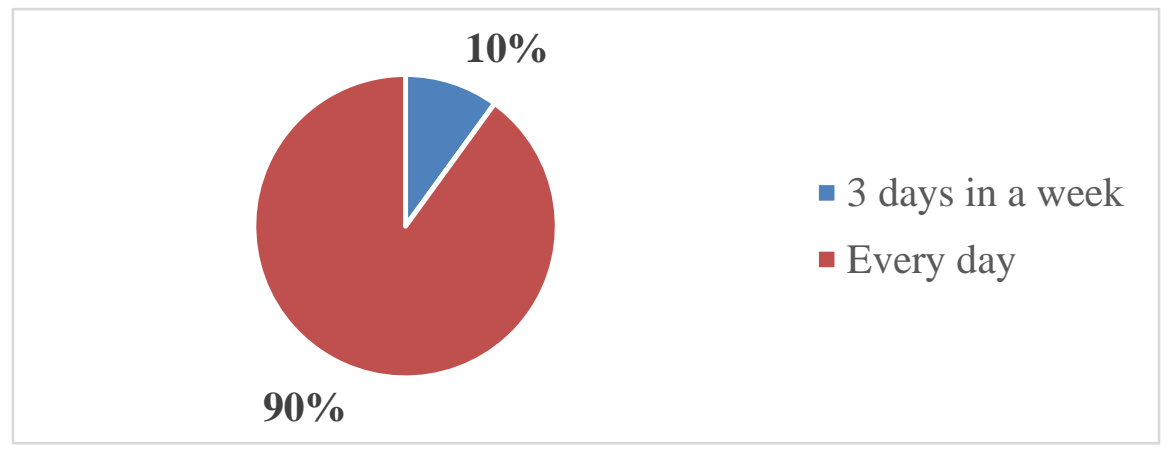

Figure 1 Time Spent on Watching YouTube Videos in One Week

Figure 2 shows that five students usually spent around five hours a day watching YouTube videos. There was also a student who watched YouTube for around six hours a day. It can be seen that most of the second graders of language students in the Senior High School spent a lot of time to watch YouTube videos in a day.

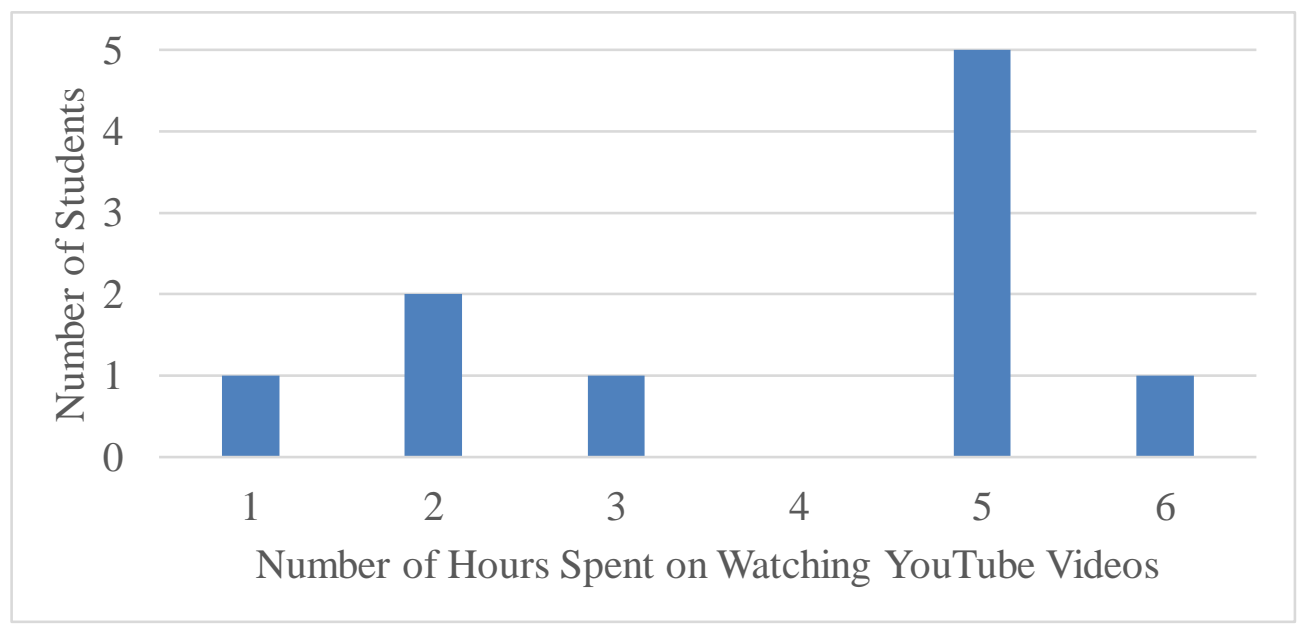

Figure 2 Time Spent on Watching YouTube Videos in One Day

From Figure 1 and Figure 2, it could be seen that the second graders of language students in the Senior High School were accessing YouTube daily and could spend around five hours a day only for watching YouTube videos. These were evidence that students highly used YouTube videos. Besides that, it proved that students enjoyed watching YouTube videos because they could spend a lot of time while watching YouTube videos.

\section{Offering a lot of language varieties}

The other advantages served by YouTube are the variety of videos' languages. YouTube enabled the students to access YouTube videos in many languages. Based on the questionnaires, the students usually accessed foreign language videos on YouTube. Figure 3 shows that $40 \%$ ( 8 students) usually watched English videos, 25\% (5 students) usually watched Indonesia videos, 20\% (4 students) usually 
watched Japanese videos, 10\% (2 students) usually watched Korean videos, and 5\% (1 student) usually watched Chinese videos.

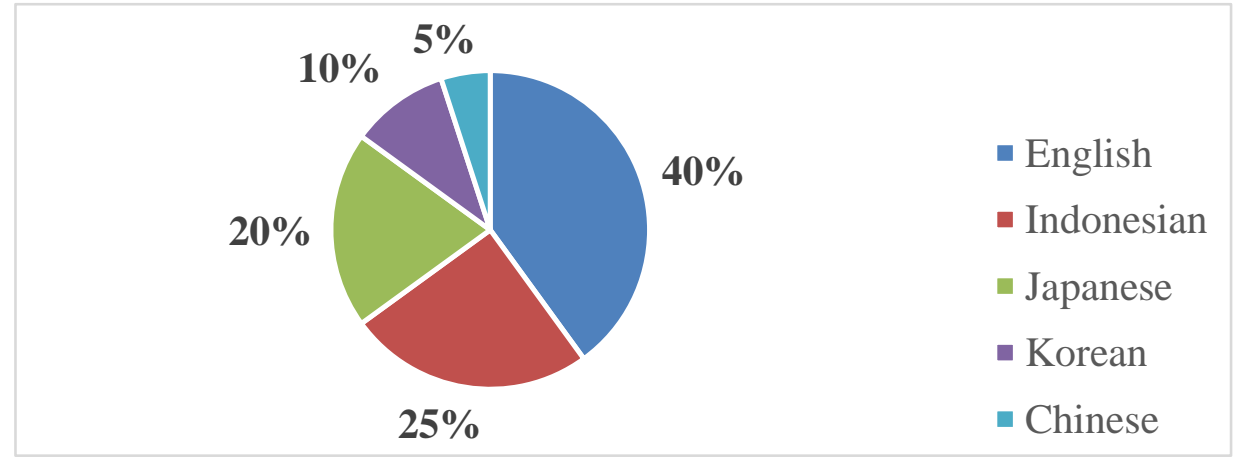

Figure 3 Language Used when Watching YouTube Videos

Furthermore, while watching the foreign language videos, all students agreed that subtitles helped them understood the videos. Then, Figure 4 shows that 67\% (8 students) usually used English subtitles, and 33\% (4 students) usually used Indonesian subtitles while watching YouTube videos.

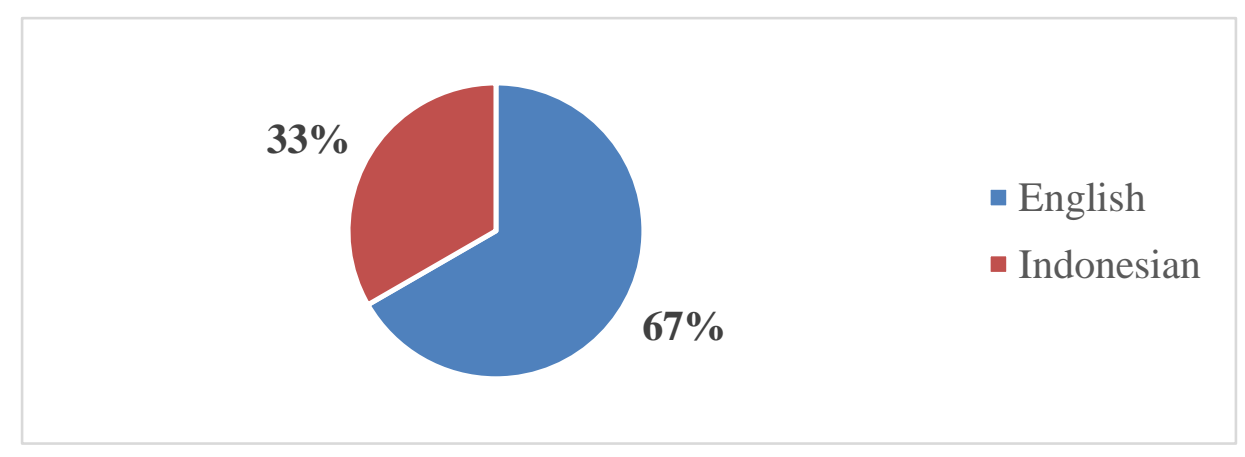

Figure 4 Languages Used on The Subtitle for Watching YouTube Videos

In the questionnaires, students said that subtitles could help them to understand the conversation that sometimes was not clear enough. Besides that, some of them said that they could understand the videos better when using English subtitles rather than Indonesian subtitles. Below were some quotations taken from the questionnaire answers:

\section{Excerpt 1:}

I like to use English subtitles rather than the other because the other languages are more difficult to be understood.

(Student 5's questionnaire answer, February 5, translated by the researchers)

\section{Excerpt 2:}

I used English subtitles because some conversations are very fast and have unclear pronunciation, so the videos are hard to be heard and understood.

(Student 10's questionnaire answer, February 5, translated by the researchers) 
From the quotations above, it could be seen that some second graders of language students in the Senior High School were preferred to use English subtitles rather than other language subtitles because English subtitles were easier to be understood. Besides that, the subtitles were useful to help the students understand the videos better.

\section{Offering a Lot of Contents with Various Purposes}

YouTube offered a lot of content for many purposes. Based on the answers to the questionnaires, students also used YouTube videos for various purposes. In Figure 5, 45\% (9 students) watched YouTube videos for academic purposes, 40\% (8 students) watched YouTube videos for entertainment purposes, and 15\% (3 students) watched YouTube videos for getting the news.

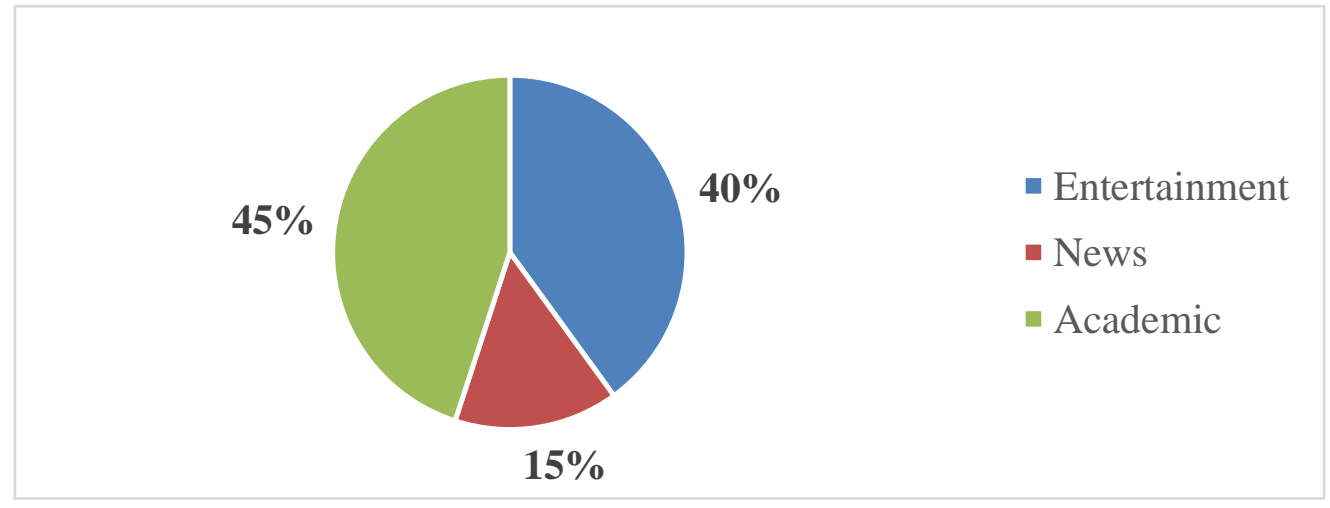

Figure 5 The Aims of Watching YouTube Videos

It could be seen that nine out of ten students used YouTube for academic purposes. Fleck, Beckman, Sterns, and Hussey (2014) claimed that many students have used YouTube videos, especially for educational purposes. Similar to that, most second graders of language students in the Senior High School also already had the awareness to use YouTube as a tool to support their learning.

\section{The Benefits Offered for Language Learning}

YouTube also offered a lot of benefits to students' language learning. As shown in Figure 6, students mentioned that the benefits of YouTube were fun (six students), accessible (4 students), and have many contents (5 students).

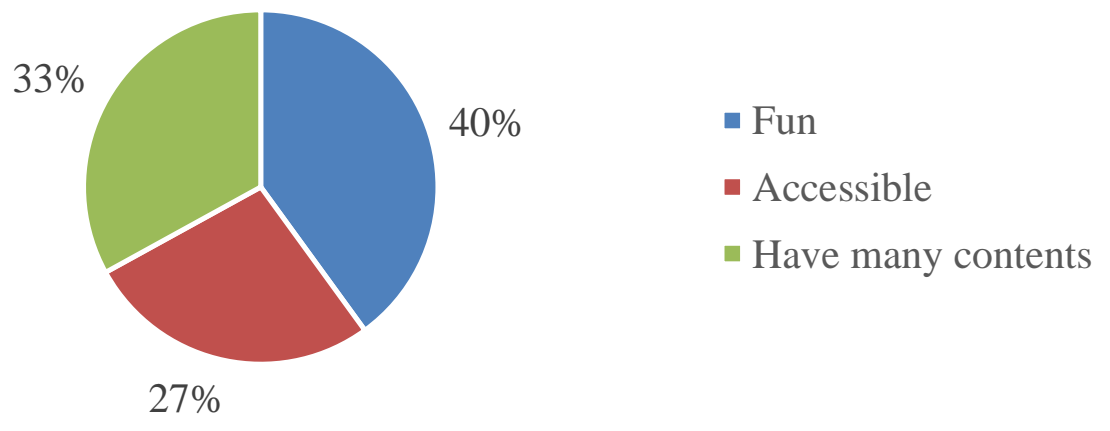

Figure 6 The Benefits of YouTube Videos on Language Learning 
Students stated that YouTube made the learning process appeared more fun which could increase their motivation to learn. Moreover, YouTube videos also very accessible which means it could be accessed everywhere. Students only needed their personal computer, laptop, or smartphone to learn using YouTube videos. Students also said that on YouTube they could find a lot of knowledge that not be taught at school. These were some quotations taken from the questionnaires answer and the interview:

\section{Excerpt 3:}

In my opinion, learning language with YouTube can be very helpful. There are a lot of things and vocabulary that I learned from YouTube, not from school.

(Student 2's questionnaire answer, February 5, translated by the researchers)

\section{Excerpt 4:}

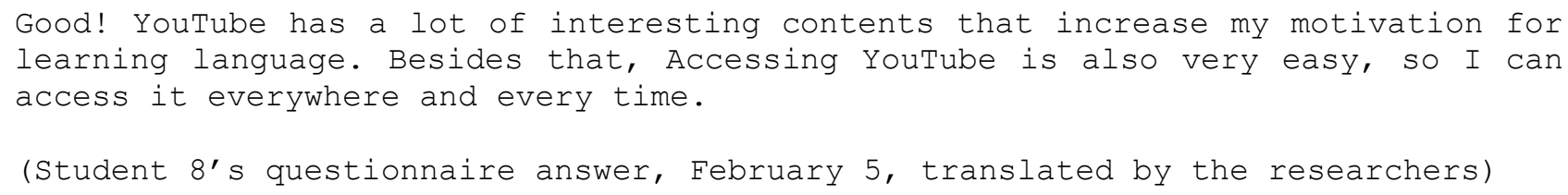

From the quotations above, it could be seen that some students agreed that YouTube videos could help them to learn language. It was similar to Muhammad's (2012) and Almurasi's (2006) statement that claimed that YouTube is one of the most effective tools in helping the students to understand their English lessons. Almurashi's (2016) research also asserted that using technology like YouTube can make the learning process more engaging for the students.

\section{Enhancing Language Skills}

According to the questionnaires, YouTube videos also helped the students to improve their language skills. Figure 7 displays that seven students claimed that YouTube could improve their vocabulary, six students claimed that YouTube could improve their listening skills, and six students claimed said that YouTube could improve their pronunciation skills.

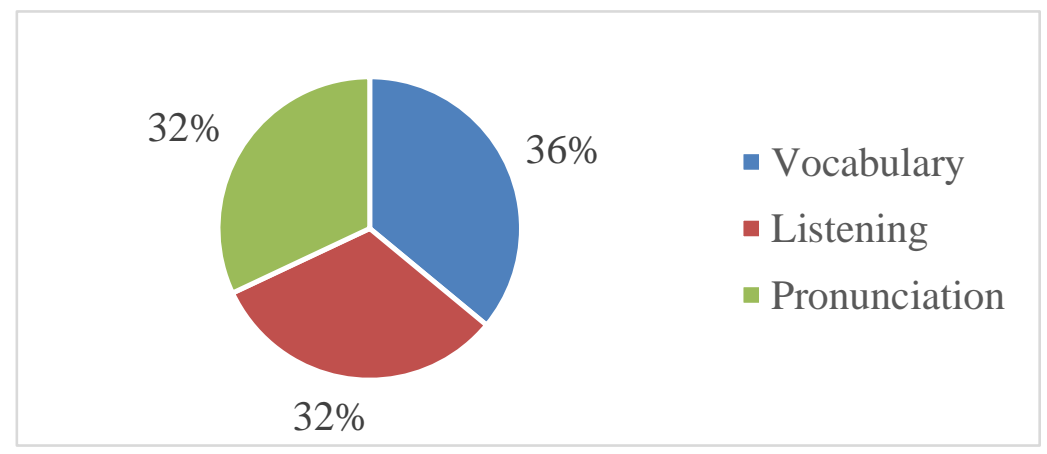

Figure 7 Students' Language Skills Influenced by YouTube Videos

\section{Improving Students' Vocabulary}

Vocabulary is one of the things that are important for students' language learning. There are a lot of ways for students to acquire vocabulary. One of the ways is through YouTube videos. From the 
questionnaire, seven students claimed that YouTube videos could help them acquire a lot of vocabulary.

\section{Excerpt 5:}

I usually use YouTube to watch movies. While I watched the movies, sometimes I found some new vocabulary. Not only learned the vocabulary, but I also learned how to use that vocabulary.

(Student 4's interview answer, February 9, translated by the researchers)

The results above were supported by Kabooha and Elyas (2018) asserting that YouTube has a big impact on improving students' vocabulary acquisition. Therefore, it could be seen that YouTube videos were beneficial to improve students' vocabulary.

\section{Improving Students' Listening skill}

Listening was considered an important skill in learning a language. Based on the questionnaires, six students agreed that YouTube videos could help them to improve their listening skills. It happened because YouTube videos consist of a lot of contents such as songs, conversations, and movies which could enhance their listening skill.

\section{Excerpt 6:}

YouTube can help me to improve my listening skills. I usually learn listening using songs or movies on YouTube.

(Student 1's questionnaire answer, February 5, translated by the researchers)

Excerpt 7:

YouTube videos are very helpful to improve my listening. It is because there are a lot of native speakers on YouTube. The authentic native speakers are very beneficial for my listening skills.

(Student 10's interview answer, February 9, translated by the researchers)

From the quotation above, it could be seen that there were ways to improve listening skills through YouTube videos. Most students usually used songs and movies to improve their listening skills. The finding above was similar to Tamelan and Listyani's (2018) study which found that there were a lot of ways for students to learn language with YouTube videos. They also asserted that videos that could help the students to improve their listening skill could be found easily on YouTube. Then, Alqahtani's in 2014 also asserted that YouTube videos give positive impacts on students' listening skills. Therefore, it can be seen that YouTube was very beneficial in improving students' listening skills.

\section{Improving Students' Pronunciation Skill}

Pronunciation was one of the language skills that enabled people to communicate effectively. Based on the questionnaires, YouTube can be used to improve students' pronunciation skills. Six students said that YouTube was useful to improve their pronunciation skills. They said that they could learn how to pronounce some words or fix their pronunciation through YouTube videos. 


\section{Excerpt 8: \\ I can also learn how to pronounce some words from native speakers on YouTube videos. There are also a lot of accents that I can choose based on my needs. \\ (Student 10's interview answer, February 9, translated by the researchers)}

From the quotation above, it could be assumed that YouTube could improve students'pronunciation skills. According to Gunada (2018), YouTube Videos can improve students' speaking aspects such as fluency, pronunciation, and grammar. Thus, YouTube was very beneficial to help the students enhance their pronunciation skills.

\section{Students' Perceptions on YouTube Videos for language Learning: The Disadvantages}

YouTube has been proven to give a lot of benefits to language learning. However, there are also some challenges or difficulties while using YouTube for language learning. In addition, Not all students agreed that YouTube Videos should be used to learn the language, For Instance, one student (student 9)asserted that he did not like to use YouTube on language learning because it made him lose focus. Moreover, according to the questionnaires and the interview, all second graders of language students in the Senior High School faced some challenges and difficulties while accessing YouTube videos for language learning.

\section{Internet Connections Problems}

The first challenge or difficulty was not all places had a good Internet connection. Even though some public places in Semarang have provided a wireless fidelity (Wi-Fi) connection, but some of them had a bad connection.

\section{Excerpt 9:}

I like to learn using YouTube videos. Sometimes the Internet connection is so bad.

It can take fifteen to twenty minutes just to watch a ten minutes video.

(Student 3's questionnaire answer, February 5, translated by the researchers)

The poor network could cause the bad connection or because there were a lot of people used the same Wi-Fi connection. The bad connection would disturb the students while they accessing YouTube videos. On the worst case, the bad connection made them can not access the YouTube videos at all. Therefore, a good connection was important for students to learn language using YouTube videos.

\section{Huge Data Plans Consumed}

Accessed YouTube videos need a lot of data plans. Moreover, the better the video quality, the more data plans were needed.

\section{Excerpt 10:}

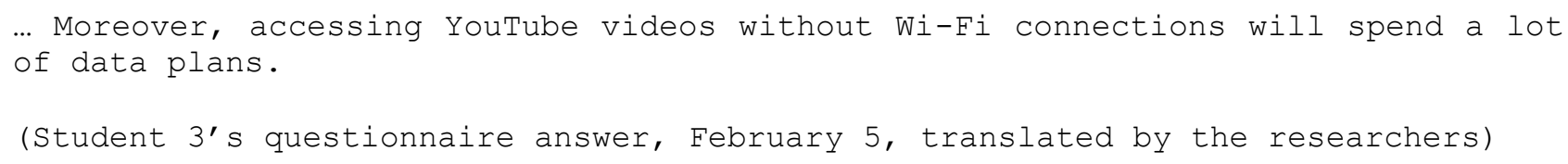


Students claimed that they spend a lot of data plans while accessed YouTube videos. Therefore, when they did not have data plans, they had to depend on Wi-Fi network that was also not always good.

\section{Unclear Sounds and Unfamiliar Vocabulary}

Some conversations on the YouTube videos were very fast. It was because the speakers were authentic native speakers. Besides that, not all of the native speakers spoke clearly. They also tended to use difficult or unfamiliar words that difficult to be understood.

Excerpt 11:

Learning using YouTube sometimes is difficult. It is because some speakers speak too fast. Besides that, there are a lot of unfamiliar words that made me confused.

(Student 2's questionnaire answer, February 5, translated by the researchers)

Without clear sounds and pronunciations, the students could not understand the videos. It made the students confused and relayed on the subtitles. However, sometimes the subtitle was false and confusing.

\section{Mismatched Subtitles}

Subtitles provided by YouTube did not always fit the conversation. The subtitles could be too fast or too slow. In some cases, the subtitles could have different meanings to the conversations.

\section{Excerpt 12:}

I faced some difficulties while learning with YouTube videos. I always watched foreign language videos with subtitles. However, sometimes the subtitles were not fit to the conversations, they could be faster or slower than the conversations.

(Student 7's questionnaire answer, February 5, translated by the researchers

The students used the subtitles because they could not understand the language. However, the subtitles were not always right. Hence, the subtitles could made them confused or lead to misleading.

\section{Making Students Lose Focus}

Next, the various contents on YouTube videos could make the students lose focus. The student claimed that the contents offered by YouTube videos could become a distraction while learning language. Instead of using YouTube videos for learning, the student would open another video that not relevant to the topic. Besides that, while learning using movies or song, they might just focus on the videos rather than the language aspect.

\section{Excerpt 13:}

I disagree because some people will be distracted to open other things. Therefore, it will be hard to focus while studying using YouTube videos.

(Student 9's questionnaire answer, February 5, translated by the researchers) 
These challenges were also supported by Gorra and Bhati's (2016) statement that said that some students may watch movies or videos that are not relevant to the topics. Students need more motivations and self-control to be focus on their learning while using YouTube for language learning.

Therefore, there were also some obstacles faced by students while learning with YouTube videos. However, despite of the disadvantages, YouTube still offer more advantages for language learning.

\section{CONCLUSION}

This study presents students' perception of the use of YouTube videos for the second graders of language students in the Senior High School. Based on the research, most students agreed that YouTube videos were very beneficial for their language learning. The students perceived that YouTube videos had some advantages and disadvantages for their language learning.

Based on the students' perceptions, there were five advantages of YouTube videos. First, YouTube has been familiar to the students. The second graders of language students in YSKI Senior High School Semarang, Central Java, Indonesia, have been proven to be very familiar with YouTube videos because most of them were accessing YouTube videos every day and could spend almost five hour a day. Second, YouTube offered a lot of Language varieties that can be choose by the students. Third, there were a lot of contents with various purposes offered by YouTube videos. Fourth, YouTube also offered many benefits for their language learning such as made the language learning process appear more fun and interesting, could be accessed easily, and provided a lot of contents. Fifth, YouTube videos can improve their vocabulary, listening skill, and pronunciation skill.

In addition, learning through YouTube also had some disadvantages. Students mentioned that bad connection network made them could not access YouTube videos. Moreover, watching YouTube videos without Wi-Fi network need a lot of data plan. Then, some conversation on YouTube videos are very fast and difficult to be understood. Besides that, the subtitles provides by YouTube were not always fit to the conversation. Then, because of the variety of content, the student may lose focus and open other videos that not related to their learning.

However, this study also has some limitations. This study only had ten participants who were the second graders of language students in that particular Senior High School. Therefore, future research with the similar methodology can be done with more participants with more class programs and grades.

Furthermore, this study also served some recommendations about the use of YouTube videos for language learning. Language teachers should be more aware about the benefits of YouTube videos as a tool for language learning. Besides that, teacher also needs to consider to use YouTube video in the classroom. Then, students can improve their language skill by using YouTube videos to learn language by themselves.

\section{REFERENCES}

Allan, M. (1985). Teaching English with video. Harlow: Longman

Almurashi, W. A. (2016). The effective use of YouTube videos for teaching English language in classrooms as supplementary material at Taibah University in Alula. International Journal of 
English Language and Linguistic Research, 4(3), 32-47. Retrieved from http://www.eajournals.org/wp-content/uploads/ The-Effective-Use-of-Youtube-Videos-forTeaching-English-Language-in-Classrooms-as-Supplementary-Material-at-TaibahUniversity-in-Alula.pdf

Bull, S., \& Ma, Y. (2001). Raising learners' awareness of language learning strategies in situations of limited resources. Interactive Learning Environments, 9(2), 171-200. doi: https://doi.org/10.1076/ilee.9.2.171.7439

Burke, S. C., Snyder, S., \& Rager, R. C. (2009). An assessment of faculty usage of YouTube as a teaching resource. The Internet Journal of Allied Health Sciences and Practice, 7(1), 1-8. Retrieved from http://kenanaonline.com/files/0060/60554/Burke.pdf

Creswell, J. W. (2014). Research design: Qualitative, quantitative, and mixed method approaches (4th edn). Los Angeles, London: Sage Publications. Retrieved from https://gul.gu.se/public/pp/public_file_archive/archive.html?

publishedItemId $=42564721 \&$ courseId $=86421 \&$ file $\mathrm{Id}=42564716$

Dawson, C. (2002). Practical research methods: A user-friendly guide to mastering research techniques and projects. Oxford, UK: How To Books. Retrieved from http://www.modares.ac.ir/uploads/Agr.Oth.Lib.21.pdf

Duffy, P. (2008). Engaging the YouTube Google-eyed generation: Strategies for using web 2.0 in teaching and learning. Electronic Journal E-Learning, 6(2), 119-130. Retrieved from http://www.ejel.org/issue/download.html?idArticle $=64$

Fleck, B. K. B., Beckman, L. M., Sterns, J. L., \& Hussey, H. D. (2014). YouTube in the classroom: Helpful tips and student perceptions. The Journal of Effective Teaching, 14(3), 21-37. Retrieved from https://files.eric.ed.gov/fulltext/EJ1060489.pdf

Gorra, V. C., \& Bhati, S. S. (2016). Student's perception on use of technology in the classroom at higher education institutions in Philippines. Asian Journal of Education and E-Learning, 4(3), 92-103. doi: https://ro.uow.edu.au/buspapers/874

Jackson, R., Camara, S., \& Drummond, D. K. (2016). What is qualitative research?. Qualitative Research Reports in Communication, 8(1), 21-28. doi: http://dx.doi.org/10.1080/17459430701617879

Kabooha, R., \& Elyas, T. (2018). The effects of YouTube in multimedia instruction for vocabulary learning: Perceptions of EFL students and teachers. English Language Teaching, 11(2), 7281. doi: https://doi.org/10.5539/elt.v11n2p72

Lonergan, J. (1984). Video in Language Teaching. New York, NY: Cambridge University

Muhammad, K. (2012). The use of YouTube in teaching English literature: The case of Al-Majma'ah Community College, Al-Majma'ah University (Case Study). International Journal of Linguistics, 4(4), 525-551. doi: https://doi.org/ 10.5296/ijl.v4i4.2930 
Roodt, S., \& Peier, D. (2013). Using YouTube in the classroom for the net generation of students. Issues in Informing Science and Information Technology, 10, 473-488. doi: https://doi.org/10.28945/1823

Syamlee, D. S., \& Phil, M. (2012). Use of technology in English language teaching and learning: An analysis. 2012 International Conference on Language, Medias and Culture, 33, 150-156. Retrieved from https://pdfs.semanticscholar.org/8a64/8bf836bbed27c1a44195aa389d8b8841 cf50.pdf

Tamelan, K. O., \& Listyani. (2018). Junior high school students' perceptions on the use of YouTube videos for learning English. Proceeding of the 11th FLA International Conferences, 44-55.

Watkints, J., \& Wilkints, M. (2011). Using YouTube in the EFL classroom. Language Education in Asia, 2(1), 113-119. doi: http://dx.doi.org/10.5746/LEiA/11/V2/I1/A09/Watkins_Wilkins 